


\title{
Socio-Economic Foundations of Trump's Domestic Policy and The Globalist Project in The United States (2016-2020)
}

\author{
DOI: https://doi.org/10.46398/cuestpol.3969.42
}

\author{
Dmitry Kolomyts * \\ Firdaus Vagapova ** \\ Renat Vagapov *** \\ Segei Ustinkin **** \\ Irina Kuvakova $* * * * *$ \\ Natalia Morozova $* * * * * *$
}

\begin{abstract}
The article considers the socio-economic dimension of former President Donald John Trump's domestic policy concept in the United States during his presidency from 2016 to 2020. The contradictions between D. Trump's policies and the concept of globalism stand out. During his domestic policy course, D. Trump sought to regain the ability of U.S. leadership to rebuild the country's big industry to achieve the independence of transnational financial capital. His policies had been partially successful and had created the conditions for a redefinition
\end{abstract}

* Ph.D. of Political Sciences, Associate Professor, Department of Regional Studies and Eurasian Studies, Institute of International Relations, Kazan (Volga Region) Federal University, Kazan, Russia. ORCID: https://orcid.org/oooo-0oo2-9891-6337. Email: kolomits@list.ru

** Ph.D. of Philological Sciences, Associate Professor, Department of International Relations, World Politics and Diplomacy, Institute of International Relations, Kazan (Volga Region) Federal University, Kazan, Russia. ORCID ID: https://orcid.org/oooo-ooo1-6876-7353. Email: yaktashlar@mail.ru

*** Ph.D. of Political Sciences, Advisor, Department for the Prevention of Extremism at Religious Grounds, Office for Monitoring Interethnic and Interfaith Relations of the Federal Agency for Nationalities (FADN) of Russia, Moscow, Senior Research Officer of International Interdisciplinary Research Laboratory "Study of World and Regional Socio-Political Processes" Nizhny Novgorod State Linguistic University, Nizhny Novgorod, Russia. ORCID ID: https://orcid.org/oooo-0oo2-5303-1682. Email: renariov@gmail.com

**** Doctor of Historical Sciences, Professor, Head of Laboratory, International Interdisciplinary Research Laboratory "Study of World and Regional Socio-Political Processes", Nizhny Novgorod State Linguistic University, Nizhny Novgorod, Director of Volga branch of the Federal Center of Theoretical and Applied Sociology Academy of Sciences Russia. ORCID ID: https://orcid.org/oooo-0003-1481-3208. Email: sv.ustinkin@gmail.com

***** Ph.D. of Sociological Sciences, Professor, Department of International Relations and Sociology, Institute of Social Sciences, Moscow; Research Assistant of International Interdisciplinary Research Laboratory "Study of World and Regional Socio-Political Processes" Nizhny Novgorod State Linguistic University, Nizhny Novgorod, Russia. ORCID ID: https://orcid.org/oooo-0oo2-0932-3573. Email: kuvakovaim1999@mail.ru

****** Ph.D. of Political Sciences, Associate Professor, Department of International Relations and World Political Processes, Research Assistant of International Interdisciplinary Research Laboratory "Study of World and Regional Socio-Political Processes" Nizhny Novgorod State Linguistic University, Nizhny Novgorod, Deputy Director of Volga branch of the Federal Center of Theoretical and Applied Sociology Academy of Sciences Russia. ORCID ID: https://orcid.org/oooo-0oo2-1335-8496. Email: 4379037@ gmail.com 
of the concept of globalism. Methodologically, the research, in reviewing Trump's globalist strategy and economic strategy, adopted a socioeconomic approach to politics that simultaneously explored geoeconomics and geopolitical issues in their dialectical interactions, including on the socio-economic dimension itself. It concludes that the U.S. elite faced the need to accommodate the interests of the American population, whether Republican or Democrat. Moreover, as asocial phenomenon, Trumpism has shown that the politics of globalism has entered a period of conceptual and resource crisis characterized by its inability to consider the interests of the American population.

Keywords: U.S. policy; socio-economic relations; globalism; regionalization, multipolar world.

\section{Fundamentos socioeconómicos de la política interna de Trump y el proyecto globalista en Estados Unidos (2016-2020)}

\section{Resumen}

El artículo considera la dimensión socioeconómica del concepto de política interna del expresidente Donald John Trump en los Estados Unidos durante su presidencia de 2016 a 2020. Se destacan las contradicciones entre las políticas de D. Trump y el concepto de globalismo. Durante su curso de política interna, D. Trump buscó recuperar la capacidad del liderazgo estadounidense para reconstruir la gran industria del país a fin de lograr la independencia del capital financiero transnacional. Sus políticas habían tenido un éxito parcial y habían creado las condiciones para una redefinición del concepto de globalismo. En lo metodológico la investigación, al revisar la estrategia globalista y la estrategia económica de Trump, adoptó un enfoque socioeconómico de la política que exploró simultáneamente cuestiones geoeconómicas y geopolíticas en sus interacciones dialécticas, incluso sobre la dimensión socioeconómica propiamente dicha. Se concluye que la élite de Estados Unidos se enfrentó a la necesidad de acomodar los intereses de la población estadounidense, ya sean republicanos o demócratas. Además, como fenómeno social, el trumpismo ha demostrado que la política de globalismo ha entrado en un período de crisis conceptual y de recursos caracterizado por su incapacidad para tener en cuenta los intereses de la población estadounidense.

Palabras clave: política estadounidense; relaciones socioeconómicas; globalismo; regionalización, mundo multipolar. 
Dmitry Kolomyts, Firdaus Vagapova, Renat Vagapov, Segei Ustinkin, Irina Kuvakova y Natalia Morozova

680

Socio-Economic Foundations of Trump's Domestic Policy and The Globalist Project in The United States (2016-2020)

\section{Introduction}

When it comes to elections in the United States, it means, first of all, clarifying who the country is economic and financial elite will stand for. The common view on this issue is that economic elites do not « put all one's eggs in one basket », that is, they share their interests between democratic and republican party. It is just a matter of greater or lesser preferences (Baltz, 2021). With regard to the 2020 elections, the issue of the value choice of voters was added. But there is another question for elections: the political choice of voters based on socio-economic preferences, that is, the impact of class preferences on political choices (Biegon, 2019).

When discussing the contradictions between Republican and Democratic Party supporters in the United States, the media focus on the contradictions in the world view. This can be explained by the fact that with the predominance of services in the economy, industrial policy becomes less visible (Gusterson, 2017; Farzanegan et al., 2021).

As a result, the interests of the North American community in the production of goods and productive entrepreneurship are on the periphery of media discussion, analysis and attention. But it is precisely the contradictions between the industrial and post-industrial parts of North American society that constitute one of the main contradictions between the Trumpist Republicans and the Democrats. It is known that Trump was in favor of the country's industrial revival, and that the Democrats were in favor of a post-industrial strategy. Some aspects of this policy and its outcomes from 2016 to 2020 are discussed in this article.

\section{Materials and Methods}

The article, in reviewing the globalist strategy and President Trump's economic strategy, adopted a socio-economic approach that explored geoeconomic and geopolitical issues in their dialectical interactions, including about the socio-economic dimension. A problem-solving approach has been taken when considering the policies of President Trump himself, as well as the objectives of his political opponents by globalists. This method examined Trump's actions in overcoming US economic de-industrialization in the face of opposition from the globalist elite. An analytical method was also used when Trump's policies were studied in the fields of migration, employment, finance, and industry. The sociological method was used to examine voters' political preferences in the United States from 2012 to 2020. The statistical method was used in the framework of the sociological method and the involvement of economic statistics. 


\section{Results}

By 2016, many in the United States had come to realize that the most powerful American TNCs and banks did not solve the problems of US citizens or North American domestic businesses. The mortgage crisis of 2007-2008 in the United States showed that all the wealth of the world that was supposed to be in the territory of that state was not really there. The money of the globalists flows past the U.S. and does not enrich the state. In the so-called "Great Stratification": for the period 1979-2007. The combined income of the richest $1 \%$ grew by $275 \%$, while the poorest $20 \%$ of American households grew by only 18\%» (Clarke and Ricketts, 2017; Biegon, 2019).

Trump needed domestic support to achieve his goals. It was therefore vital for him to keep his promises. In his statement, he blamed the immigrants and the foreign campaigns. Thus, with one proposal, he solved four issues: the development of national capitalism, the maintenance of the nation-State, the prevention of unemployment, and the fight against crime.

According to many analysts, Trump's policies had their effects. In the Rust Belt, stretches of riverway are crowded again with coal barges. And local business leaders believe in the Trump Bump because they see it in their order books and balance sheets. In the Coal Belt, there's been delight at the rescinding of Obama's Clean Power Plan. According to a report by the United States Department of Labor's Bureau of Labor Statistics in September 2019, the United States' unemployment rate "reached a record low since December 1969 and amounted to $3.5 \%$ » is 5.8 million men (Guliyev, 2020). As early as 2018 in Davos, Trump announced: Since my election, we've created 2.4 million jobs and that number is going up very, very substantially. It is noteworthy that he said, continuing his talk: African-American unemployment reached the lowest rate ever recorded in the United States and so has unemployment among Hispanic-Americans (Nelson, 2019). The success of Trump's policy was also recognized by the opposition. It is acknowledged that the successes at the end of 2019 can be considered as the «strong stock market, record low unemployment, low inflation», "petrol prices below average, tax cuts, deregulation campaign...» (Regilme, 2019) In doing so, Trump articulated a commitment to the philosophy of North American imperialism, stating; There has never been a better time to hire, to build, to invest, and to grow in the United States. America is open for business and we are competitive once again (Farzanegan et al., 2021).

The Republicans' tax stance under Trump remained the same: the drive to cut taxes. During Trump's presidency, taxes were reduced on so-called C corp, one of the most common types of private enterprises in the United States, including large ones, as well as on individual business firms and 
Dmitry Kolomyts, Firdaus Vagapova, Renat Vagapov, Segei Ustinkin, Irina Kuvakova y Natalia Morozova

682

Socio-Economic Foundations of Trump's Domestic Policy and The Globalist Project in The United States (2016-2020)

partnerships with various flexible organization schemes (Lacatus, 2020). Moreover, Trump proposed lower-wage taxes. As a result, 40\% of small businesses considered themselves Republicans in 2020, compared to 29\% who considered themselves Democrats, while the number of undecided people decreased to 40\% (Guliyev, 2020). Small and medium-sized businesses' views of Trump's presidency were strongly influenced by the announced COVID 19 pandemic. It particularly affected those who were unable to compensate for losses despite State aid or health insurance, and who chose to deny Trump support (Hall, 2020). While others who had successfully survived the pandemic by the end of 2020 have maintained confidence in the incumbent President. In general, during his presidency, Trump managed to secure the support of the business.

Trump's policy of limiting migration from Latin America proved successful. Already by the beginning of 2020 so-called «caravans of migrants» from Mexico disappeared. The reason for this was the agreement that Trump made with Mexican President Andrés Manuel López Obrador, whereby the Mexicans unilaterally closed the border with Guatemala and the United States, and the remaining migrants either stayed in Mexico or returned to their countries. The number of migrants in July 2019 was 87,000 and the month before that was 144,000 (Nelson, 2019). At the same time, in April 2019, 16,100 illegal migrants were detained on the border with Mexico; in June - 30,700 in July - 38,400; in August - 46,800 (Biegon, 2019; Restad, 2020).

Overall, by the end of 2019, the number of migrants detained at the southern border of the United States had fallen by 75 percent compared to May of the same year. Mexico stopped about 150,000 migrants from going to northern Mexico. Besides, in 2019, 64,000 illegal border crossings were transferred from the United States to Mexico (Mulich, 2020). Evidence suggests that irregular migration has not stopped, and several illegal immigrants have entered the United States, but it has declined significantly. Trump's other action was to build a wall on the border with Mexico, which was not completed but remained an important part of his anti-migrant policy.

The persecution of Trump personally unleashed by the democratic globalist elite led to the concentration of its so-called «nuclear electorate» around Republicans and Democrats: Protestants, whites, farmers, African Americans, Hispanics, LGBT community, gun owners, etc. «In the «Bible belt» Protestants see Trump as their own, just like them, a victim of bullying by the liberal elite. In the «solar belt» along the Mexican border, his plans to combat illegal immigration are strongly supported». The struggle to implement the new policy towards migrants has spread to the US courts (Regilme, 2019). At the same time, the Latin-speakers themselves oppose the influx of migrants across the border, realizing that 
this leads to an increase in crime and unemployment. The important thing here is that Trump continued to fulfill his promises, thereby retaining support among those of his supporters who considered illegal migration a big problem for the United States.

Likewise, Conservative Trumpists associate achievements in domestic politics with achievements in foreign policy. In an interview with The Wall Street Journal, US Trade Representative Robert Lighthizer said, «the tariffs are helping to bring industrial jobs back to the US» and «the number of jobs in the sector has grown by 400,000» between November 2016 and early March 2020 (Guliyev, 2020). As his victory, he announced that «out of 200 billion dollars, China will spend half ( 50 billion dollars a year) on the purchase of agricultural products from American farmers who unanimously vote for him in the elections» (Restad, 2020). China was forced to make concessions on other issues as well.

The economic goal is expressed something like this: we will get rich, and everyone will come to us for technology, loans, money. It is believed that the goal of Trump's policy is «to level the playing field in his giant domestic market and to resist theft of intellectual property» (Biegon, 2019). Trumpists managed to solve the ideological task of creating an «image of China as an enemy», which "became entrenched in the minds of Americans» and «the abolition of duties on Chinese goods» is no longer being discussed (Nelson, 2019). His opponents from the liberal camp accuse him only of hypocrisy, since it was in China that Trump placed some of his orders. They also say that further all the projects of the President of the United States will not be successful. Nevertheless, these are weak arguments (Mulich, 2020).

However, the political confrontation noticeably turns into falsifications and the creation of false facts. For example, Wall Street Journal experts «note that this two-thirds increase occurred even before the United States introduced the first round of duties on Chinese goods in July 2018. By the beginning of 2020, even before the States faced the pandemic, the growth in industrial employment had stopped (Interfax.ru, 2020). In fact, the decrease in unemployment was hardly noticeable in 2018 (by 0.1-0.3\%), but the increase in unemployment still turned out to be directly dependent on the outbreak of the COVID-19 epidemic - it was in March that there was a sharp jump in unemployment by $11.3 \%$ (Lacatus, 2020).

The deep internal contradictions among the population of the United States should be considered. A country that declared but did not become a "melting pot" of nations, did not create a true "American nation." And the growth of ideological contradictions, up to the "idiosyncrasy" and "incapacity for constructive cooperation" of the opposing forces, at least "by the Republicans already in 1994", further and further led people away to the political flanks (Restad, 2020). 
Dmitry Kolomyts, Firdaus Vagapova, Renat Vagapov, Segei Ustinkin, Irina Kuvakova y Natalia Morozova

684

Socio-Economic Foundations of Trump's Domestic Policy and The Globalist Project in The United States (2016-2020)

With Trump, a strange feature in the political life of the United States was revealed in that the President's course is personal, and is named Trump's course and "Trumpian", and the "globalists» and "democrats» acting against him are anonymized. Based on this, one gets the impression that Trump is a loner opposing the US Democratic Party. It is backed by major US campaigns, the military-industrial complex, and most of the US's population.

Trump opposed the Fed, which, according to Trump, raised rates and continued to print extra money (Mulich, 2020). The decision of the US Federal Reserve to cut the refinancing rate for the first time in the last decade by only 0.25 percentage points should be considered a minor victory for Trump (Wojczewski, 2020). There is another opinion that Trump could not resist the Fed, that wolves of Wall Street showed Trump who was the boss and who would determine the level of interest rates in the economy. But we observed a certain confrontation between the President of the United States and the Fed (Hall, 2020).

A feature of the political choice of voters in the United States is value. In the United States, as a state with a significant share of services in the economy, which means a fairly high level of income for a large part of the population, political choices rarely regard the income directly. Many people vote based on value and ideological preferences, which are especially advantageously highlighted in the media, showing the confrontation of some groups against others. The 2020 presidential election did not add consensus to North American society (Lacatus, 2020). Brexit and then Trump's election is a reflection of a deep crisis in Western society that no one wanted to notice. And the example of "yellow vests" in France, the League in Italy, and "Alternatives for Germany" in Germany" shows that "in Western societies there was a rebellion of a significant part of the population, a populist rebellion" (Regilme, 2019; Wojczewski, 2020). After the crisis in 2008, "millions of Americans were left homeless" plus "a deep economic split in American society": job cuts due to technological development affect both workers and employees (Nelson, 2019).

In the liberal-minded part of Canada, Trumpism is assessed as an extreme right-wing movement, inspired by Trump in its racism and xenophobia, which will increase the pressure on society (Mulich, 2020). Regionalization as a global trend has captured the United States as well. Trump only strengthened and sped up the US advance towards isolationism, which became noticeable even under Barack Obama (Restad, 2020).

Since there were no significant changes in demographic, economic, and social relations from 2015 to 2020 , the state voting only confirmed the development of the existing patterns (Guliyev, 2020) (Figure 1, Figure 2). 


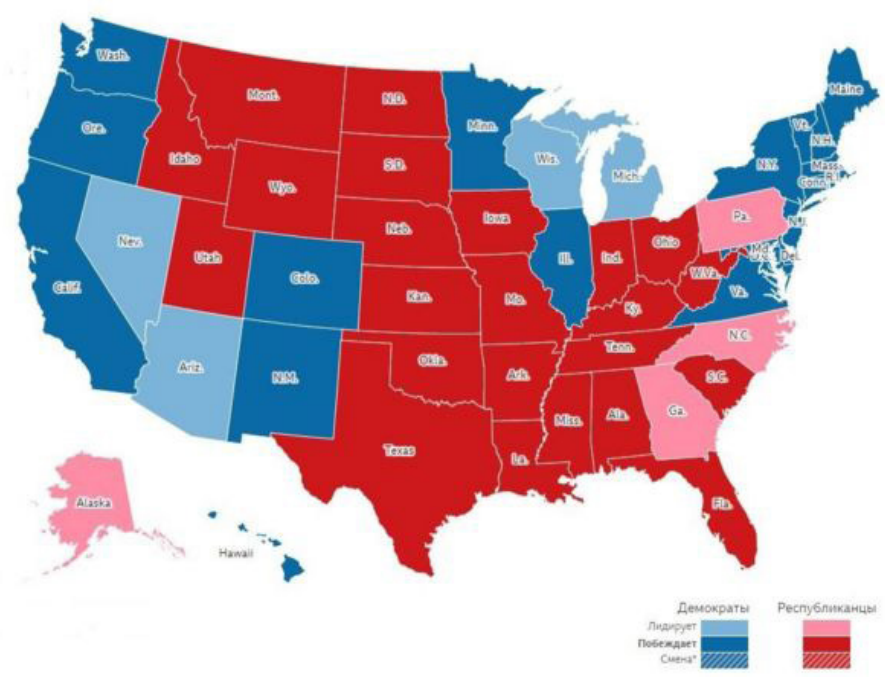

Figure 1. Source: The United States Elections 2016: all results 9.11.2016 (Steff and Tidwell, 2020; Wojczewski, 2020).

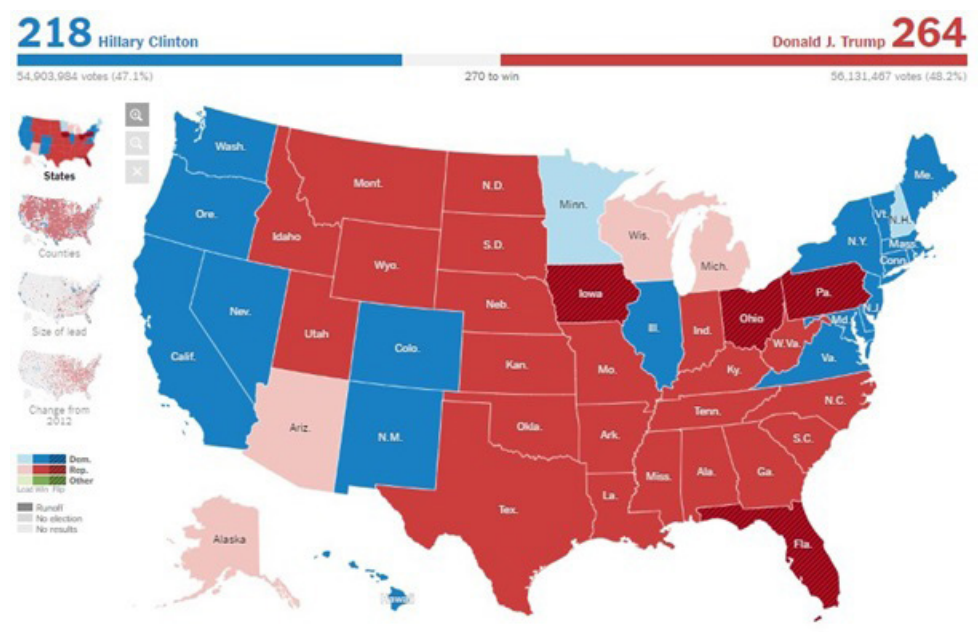

Figure 2. Results of the US presidential election: How Biden and Trump can win (Steff and Tidwell, 2020; Wojczewski, 2020). 
Dmitry Kolomyts, Firdaus Vagapova, Renat Vagapov, Segei Ustinkin, Irina Kuvakova y Natalia Morozova

\section{Discussion and Conclusion}

In the United States, the polarization of the electorate in relation to Republicans and Democrats continued: the number of undecideds has fallen by about 2 times since 1992. Moreover, Trump eventually received 73.8 million votes and 62.9 million in 2016 (Gruszczynski and Lawrence, 2018; Restad, 2020). By 10 million more votes in 2020. That means that support for his course has increased. Financiers, industrialists, representatives of the construction industry, property owners and hired production laborers supported Trump in 2020 (Hall, 2020). The Latin Americans' choice of Trump was based by his economic policies in favor of the poor, and the choice of women was based on his policy against street violence (Lacatus, 2020; Wojczewski, 2020).

Consequently, the United States elite was faced with the need to accommodate the interests of the self-determined US population in 2020, whether they are Republican or Democratic. As a social phenomenon, Trumpism has shown that pursued primarily by the US Transnational Corporations, the policy of globalism has entered a period of conceptual and resource crisis that is unlikely to emerge without consideration of the interests of the US population.

The aspiration of the globalist elite to «forget» Trumpism «as a terrible dream» is groundless, which clearly reads in the speeches of supporters of the Democrats. Trump's supporters can't abandon their values and desire to defend their socio-economic rights connected to the US state, but they don't care about the globalist project. Obviously, that the situation inside the United States has taken on the features of a long-term crisis, connected to economic, social and value contradictions.

\section{Acknowledgments}

Estimates when considering the electorate of Republican-Trumpists and Democrats mainly revolve around the ideological and value preferences of voters, but differences between parties are also socio-economic. Conservative supporters seek to preserve the nation-state of North America with all the consequences that follow national industry, financial independence and the values of the first settlers based on religious Protestant ethics. And all three components contradict the globalist project. There was a growing phenomenon of voting for Trump and hired laborers, and representatives of small, middle, and big capital. Under these circumstances, the increased electoral support for Trump showed that the internal crisis in the United States became systemic and tended to deepen in 2020. 


\section{Bibliographic References}

BALTZ, Matthew J. 2021. “Americanism not globalism will be our credo!': An analysis of the economic nationalism (s) of Trump's administration and an agenda for further research" In: Nations and Nationalism. Vol. 34, pp. 345-362.

BIEGON, Rubrick. 2019. "A populist grand strategy? Trump and the framing of American decline" In: International Relations. Vol. 33, No. 4, pp. 517539 .

CLARKE, Michael; RICKETTS, Anthony. 2017. "Donald Trump and American foreign policy: The return of the Jacksonian tradition" In: Comparative Strategy. Vol. 36, No. 4 pp. 366-379.

FARZANEGAN, Mohammad Reza; FEIZI, Mehdi; GHOLIPOUR, Hassan F. 2021. "Globalization and the Outbreak of COVID-19: An Empirical Analysis" In: Journal of Risk and Financial Management. Vol. 14, No. 3, pp. 105 .

GRUSZCZYNSKI, Lukasz; LAWRENCE, Jessica. 2018. “Trump, International Trade and Populism" In: Netherlands Yearbook of International Law, TMC Asser Press, The Hague. Vol. 49, pp. 19-44.

GULIYEV, Farid. 2020. “Trump's “America first” energy policy, contingency and the reconfiguration of the global energy order" In: Energy policy. Vol. 140, No. pp. 111435-111472.

GUSTERSON, Hugh. 2017. "From Brexit to Trump: Anthropology and the rise of nationalist populism" In: American Ethnologist. Vol. 44, No. 2, pp. 209-214.

HALL, Jonny. 2020. "In search of enemies: Donald Trump's populist foreign policy rhetoric" In: Politics. Vol. 41, No. 1, pp. $48-63$.

LACATUS, Corina. 2020. "Populism and President Trump's approach to foreign policy: An analysis of tweets and rally speeches" In: Politics. No. 41, No.1, pp. 0263-0275.

MULICH, Jeppe. 2020. "An imperial imaginary: Or Rosenboim, The emergence of globalism: visions of world order in Britain and the United States, Princeton, NJ, Princeton University Press, 2017, ISBN 9780691168722 (hbk), ISBN 9780691191508 (pbk). Vol. 352, pp.18-22.

NELSON, Douglas R. 2019. "Facing up to Trump administration mercantilism: The 2018 WTO trade policy review of the United States" In: The World Economy. Vol. 42, No. 12, pp. 3430-3437. 
Dmitry Kolomyts, Firdaus Vagapova, Renat Vagapov, Segei Ustinkin, Irina Kuvakova y Natalia Morozova United States (2016-2020)

REGILME, Jr Salvador Santino F. 2019. "The decline of American power and Donald Trump: Reflections on human rights, neoliberalism, and the world order" In: Geoforum. Vol. 102, pp.157-166.

RESTAD, Hilde Eliassen. 2020. "What makes America great? Donald Trump, national identity, and US foreign policy” In: Global Affairs. Vol. 6, No. 1, pp. 21-36.

STEFF, Reuben; TIDWELL, Alan. 2020. "Understanding and evaluating Trump's foreign policy: a three frame analysis" In: Australian Journal of International Affairs. Vol. 74, No. 4, pp. 394-419.

WOJCZEWSKI, Thorsten. 2020. "Trump, populism, and American Foreign policy” In: Foreign Policy Analysis. Vol. 16, No, 3, pp. 292-311. 

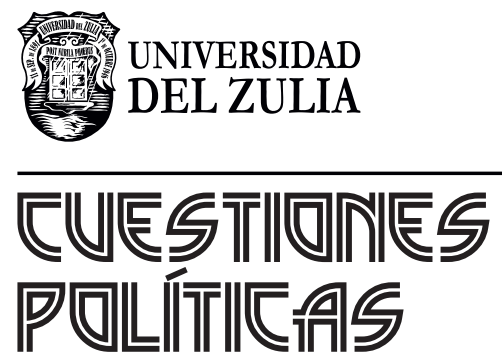

Vol.39 No 69

Esta revista fue editada en formato digital y publicada en julio de 2021, por el Fondo Editorial Serbiluz, Universidad del Zulia. Maracaibo-Venezuela 